\title{
War
}

\section{Joy Rohde}

\author{
University of Michigan \\ joyrohde@umich.edu
}

This material has been published in Society on the Edge: Social Science and Public Policy in the Postwar United States, edited by Philippe Fontaine and Jefferson Pooley (https://doi.org/10.1017/9781108765961). This version is free to view and download for private research and study only. Not for re-distribution or re-use.

Joy Rohde. "War" In Society on the Edge: Social Science and Public Policy in the Postwar United States, edited by Philippe Fontaine and Jefferson D. Pooley, 290-321. Cambridge: Cambridge University Press, 2020. https://doi.org/10.1017/9781108765961.010 
Joy Rohde, University of Michigan, joyrohde@umich.edu

doi

IN 1959, in the midst of escalating tensions with the Soviets over the status of Berlin, political scientist Joseph Schneider asked, "Is war a social problem?" His answer, penned for the Journal of Conflict Resolution (JCR), was a firm "No!"1 Social problems were challenges that caused so much human suffering or so impeded social progress that they demanded alleviation. ${ }^{2}$ War, Schneider argued, "is a necessary condition for the life of the group." 3 It was a natural feature of a state-based international system and a tool for maintaining social cohesion within nations. Far from a social problem, war was a social institution fundamental to the modern political and social order.

Just fifteen years earlier, many social scientists thought quite differently about war. In 1943, members of the Society for the Psychological Study of Social Issues issued a manifesto that insisted, "War can be avoided: war is not born in men; it is built into men." By 1945, over half of the American Psychological Association's membership endorsed the manifesto's claim that war was a pressing social problem requiring "social engineering on a worldwide scale." 4 This was just one expression of a broader social scientific effort to end war that had begun in earnest after World War I. Drawing on social psychology, political science, international law, sociology, and anthropology, scholars had sought since at least the 1920 s to create a globally minded citizenry willing to trade national allegiances for international peace.

By the early 1950s, the internationalist project was widely rejectedeven by some of its proponents-as an idealistic fool's errand. The causes of this shift were multiple. The failure of democracy in Europe in the 1930 s called the rationality and reliability of any public-let alone a global one-into serious question. The deepening animosity between the United States and the Soviet Union in the late 1940s and early 1950 made global cooperation and peace seem farfetched. The threat of nuclear war dramatically raised the stakes of foreign affairs and provoked new strategic questions. In this context, many social scientists recast war as a national security challenge. Rather than an aberration to be exorcised, war was a tool of statecraft, one that could be wielded wisely-waged when necessary, threatened when beneficial, and always rationally managed - by social-scientifically informed government officials. Figures in the nation's growing national security agencies invested their resources in these projects, not

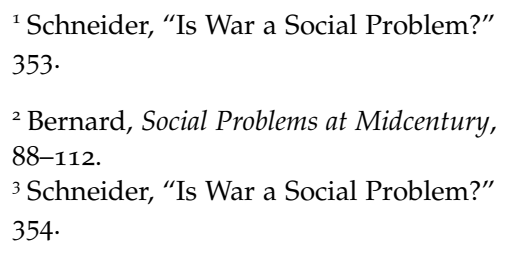

${ }^{4}$ Quoted in Herman, Romance of American Psychology, 78, 79. 
those geared toward fostering international peace, further eclipsing research that treated war as a social problem.

War was an intellectually generative subject. During the 1950s and 1960s, social scientists pursued a dizzying variety of approaches to armed conflict, including realist international relations theory, game theory, political-military gaming, modernization theory, and quantitative statistical investigations of war's causes. These intellectual traditions sometimes overlapped and sometimes conflicted. While they bore methodological continuities from earlier eras, they represented ideological departures from the interwar period. Each further moved social research away from the values of the social problems tradition and toward managerial approaches to conflict. With an influx of government funding, social scientists shifted their audiences from imagined democratic publics and new international organizations and toward the political and military elites in American national security and foreign policy agencies.

But for some social scientists, scholarly relevance to war would be their undoing. As modernization theory, psychological warfare schemes, and other approaches appeared responsible for at least some of the American failures in the Vietnam War, security-funded social science became synonymous with military hubris and defeat. In the wake of failed battles for hearts, minds, and hamlets, most anthropologists, sociologists, and psychologists withdrew from the study of war. By the middle of the 1970s, war was almost exclusively the domain of political science, and in particular the field of international relations. Under the banner of neorealism, international relations scholars would continue to seek theories, models, and quantitatively proven laws that helped government officials threaten and wield conflict in ways that benefited American national security.

A glimmer of the social problems approached remained in the social sciences even as the security frame gained ground. Interdisciplinary scholars in the field of peace studies toiled away at the margins of the social sciences, seeking the knowledge that would lead to disarmament and peace. Other social scientists continued to attend to the social problems that war could cause or exacerbate, like civilian morale crises, nuclear attack-induced psychological disturbances, or the threats that the military-industrial complex posed to democratic values and institutions. (These subjects are beyond the scope of this chapter.)

The chapter is divided into three parts. The first traces the brief moment in which social scientists viewed war as a social problem demanding international expert reforms. The second explores the period between the end of World War II and the late 1960s, an era in which the social problems approach was replaced by an array of intellectual traditions aimed at wielding war wisely and efficiently. The 
final section recounts the devastating impact of the Vietnam War on multiple fields, demonstrating that by the late 1970s, war was a security problem, the domain of political scientists intent on maintaining and expanding American dominance in the face of supposedly ruthless enemies.

\subsection{War's Brief Career as a Social Problem}

In 1942, the world powers were engulfed in their second major war in twenty-five years. University of Chicago political scientist and law professor Quincy Wright ventured a diagnosis: "The lack of consciousness in the minds of individuals that they were related to the world-community" was to blame for World War II. 5 Advances in modern technology, the development of transnational economic relationships, and the spread of modern communications knit the globe together such that "economic, political, and cultural conditions in the most distant countries" affected most people's lives. ${ }^{6}$ Political, social, and economic institutions, however, had yet to adapt to these changes. Influenced by the Chicago School theories of social maladjustment and cultural lag, Wright argued that wars were caused by the misfit between the fact of global interdependence, on the one hand, and humanity's outmoded institutional and psychological commitments to national sovereignty, on the other.

Wright's argument implied that war was a social problem that demanded social scientific solutions. Treating war as such might seem unusual, for the social problems frame implied the existence of a cohesive society with shared values and norms. War, by its very nature, implied the existence of separate communities defined by mutual animosity. In fact, Wright argued, the outmoded myth that people lived in separate communities was precisely what made war a social problem. War was caused by the failure of the world's citizens to recognize their mutual social bonds - to embrace the fact that peoples were no longer a collection of autonomous nations, but were themselves a society. By convincing world leaders and the public that war was, in fact, a social rather than a legal or political problem, scholars could perhaps eradicate it.

Wright's diagnosis appeared in his mammoth A Study of War. The book grew out of a series of meetings convened by Wright and political scientist Charles Merriam in 1926, in which faculty across Chicago's social sciences united to plan an interdisciplinary attack on the intellectual problem of war. The book's two volumes were the product of sixteen years of research by Wright and dozens of collaborators, including Bernard Brodie, Fay Cooper-Cole, Harold Lasswell, and Jacob Viner. Their investigations, sixty-six in total, drew widely
${ }^{5}$ Quoted in Selcer, Postwar Origins of the Global Environment, 3.

${ }^{6}$ Wright, Study of War, 1347 . 
from history and political science, law and economics, and psychology and sociology. Funded by the Rockefeller and Carnegie philanthropies, the Social Science Research Council, and the University of Chicago, the project subjected the study of war to the empirical rigors and interdisciplinary commitments of Chicago-style social science.7 Appropriate for foundation-funded work, A Study of War also sought to put social scientific knowledge in service of reform. While Wright dedicated the bulk of his 15,000 pages to scholarly investigation, he concluded by suggesting how social science could help create a "warless world." 8 Peace would follow from the creation of "international and supranational institutions able to adapt individual attitudes, social symbols, public opinions and public policies in every part of the world to modern conditions" of interdependence. 9 Interdisciplinary research into the relationship between psychology and political behavior, public opinion and group formation, and a variety of other subjects would underlay widespread educational efforts to replace "narrow, self-centered" nationalist attitudes with a "widespread sense of world citizenship" shared by everyday citizens and politicians alike. ${ }^{10}$

Wright was far from the only scholar to argue that expert-educated publics were the surest route to ambitious reform. His arguments fit firmly within the Deweyan and Progressive commitments to research, public education, and public deliberation as tools that could establish an enlightened world order. For Wright, as for Dewey, appeals to reason could reshape social organization. Wright's arguments also resonated with the optimistic post-World War I pursuit of an international order that commanded attitudinal and cultural affinities as well as legal and political foundations. ${ }^{11}$

If the solution to the problem of war lay in the creation of a psychologically and politically salient world community, the creation of the United Nations at the end of World War II was a step in the right direction-but only a step. Wright warned that peace would elude humanity until nations were willing "to sacrifice a considerable part of their sovereignty."12 The challenge of cultivating international citizens who were psychically aware of their international ties and tolerant of cultural diversity motivated a number of postwar social research projects. The United Nations Educational, Scientific, and Cultural Organization (UNESCO), for example, spearheaded an international, interdisciplinary study of "Tensions Affecting International Understanding" shortly after the end of World War II. Led by University of Michigan sociologist Robert C. Angell, the "Tensions" project enlisted psychologists, political scientists, anthropologists, and communications experts in an effort to identify the factors that caused widespread conflict and those that fostered international
${ }^{7}$ Griggs, "A Realist before 'Realism.' "

${ }^{8}$ Wright, Study of War, 1326.

${ }^{9}$ Wright, Study of War, 1332.

${ }^{10}$ Wright, quoted in Throntveit, "A Strange Fate," 365.

${ }^{11}$ Bessner, Democracy in Exile, 78-79 and Throntveit, Power without Victory.

${ }^{12}$ Wright, quoted in Griggs, "A Realist before 'Realism,'" 88. 
understanding and tolerance. They carried out interdisciplinary empirical studies of "the distinctive character" of national cultures that impeded integration; gauged nationalist and discriminatory attitudes via public opinion surveys; and identified the roles that cultural differences, psychological maladjustment, technological change, and other factors played in generating understanding and aggression. ${ }^{13}$ Project participants hoped to design educational programs to reduce tensions, institutionalize "tolerance as a cross-cultural principle," and create the conditions for lasting peace. ${ }^{14}$

While the aspiration to tame war through global social and political reform aligned with the mission of the United Nations, the effort also drew its fair share of scholarly critics. In particular, the project to end war attracted scorn from social scientists skeptical of its Deweyan faith in democratic publics. In the early 1920s, scholars in Europe and the United States questioned whether the public could play any beneficial role in foreign policy. ${ }^{15}$ The rise of antiSemitic and fascist regimes in the 1930s seemed to reinforce their suspicion that the public that liberal internationalists sought to remake as world citizens might actually be profoundly irrational and unreliable. The European crisis of democracy sapped the faith of European thinkers like German sociologist Hans Speier in the potential of participatory democracy. Speier, who emigrated to the United States in 1933, began his career as an advocate of democracy. But the rise of Nazism led him to reject the "Enlightenment conceptions of progress, utopianism, and human perfectibility" implied by a social scientific commitment to democratic participation. ${ }^{16}$ Speier's fellow émigré, political scientist Hans Morgenthau, also rejected notions of liberal progress and human perfectibility. Morgenthau's approach to international affairs was rooted in a conviction that humans were motivated above all by the quest for domination. No organization or educational intervention could eradicate the struggle for power from human relationships. The conviction that war was a social problemone that could be eradicated through mutual understanding-was, for Morgenthau, idealistic sentimentalism. ${ }^{17}$

Events in the five years after World War II seemed to reinforce Morgenthau's and Speier's skepticism of liberal internationalist projects. Deepening enmity between the United States and the Soviet Union dimmed hopes for lasting peace. As it increasingly seemed that US survival might depend not on international cooperation, but on finding a way to maintain the nation's unequal share of world power in the face of a ruthless foe, Morgenthau's star rose. Shortly after the war, he joined the University of Chicago faculty. His hardnosed rejection of liberal internationalism and human perfectibilitya position referred to as "realist," and opposed in the 1930 and

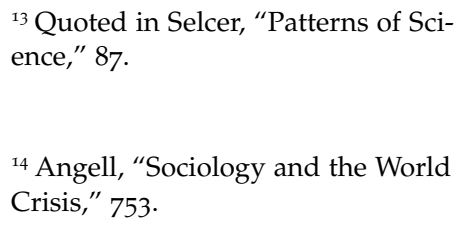

${ }^{14}$ Angell, "Sociology and the World Crisis," 753 .

${ }^{15}$ Rietzler, "International Experts, International Citizens."

\footnotetext{
${ }^{16}$ Arthur Vidich, quoted in Bessner,
} Democracy in Exile, 74.

\footnotetext{
${ }^{17}$ Greenberg, Weimar Century, chap. 5 and Gunnell, Descent of Political Theory, 209.
} 
1940 to the supposed "idealism" of internationalism-earned him a reputation as a leading theorist in the nascent political science subfield of international relations. ${ }^{18}$ His methodological approachqualitative, contextual, often historical analysis-denied the possibility that politics could be known scientifically.

For Morgenthau and other realists, war was not a social problem. It was, instead, a manifestation of the "struggle for power," which Morgenthau declared in his influential Politics among Nations (1948) "universal in time and space" and "an undeniable fact of experience."19 For realists, the international system was, and always would be, anarchical. The social scientist's purpose was not to change public perceptions and values through research and education. Instead, social scientists should assist policy elites, providing wise counsel as they pursued the national interest against enemies devoid of moral standards. ${ }^{20}$ Morgenthau's realist theory provided a compelling expression of sentiments and anxieties widely held by American statesmen in the late 1940s and 1950s. George Kennan, whose influential "Long Telegram" helped to establish Cold War containment policy, insisted that policymakers and their advisers "dispense with all sentimentality and day-dreaming; ... our attention will have to be concentrated everywhere on our immediate national objectives" in order to guarantee national survival. ${ }^{21}$ Policymakers and diplomats, including Dean Acheson, Paul Nitze, and Henry Kissinger, regularly referenced Morgenthau's ideas to support their policy positions. ${ }^{22}$ In this intellectual and policy climate, social scientific projects to cultivate international cooperation withered. Wright's internationalist message in A Study of War was largely forgotten by decade's end. ${ }^{23}$ The loss of US nuclear hegemony in 1949 broadened concerns that the United States was a fragile democracy beset by merciless foes. With internationalists increasingly labeled communist sympathizers by the early 1950s, American membership in the United World Federalists, an international organization advocating world government, declined precipitously. ${ }^{24}$ In 1951 , the University of Chicago Committee to Frame a World Constitution terminated its work in failure. Italian exile G. A. Borgese, one of the committee's founders, explained that "the worlds are two. They can fight it out or they can come to a compromise... . They cannot join in peace."25 That same year, Angell admitted that the UNESCO "Tensions" project underestimated the moral and cultural divisions among nations. In his presidential address to the American Sociological Society, he conceded that "it seems almost inconceivable that the Soviet Union and the United States could accept a common supranational authority of any kind." 26

Angell was not willing to give up his faith that social science had
${ }^{18}$ Greenberg, Weimar Century, chap. 5 .

${ }^{19}$ Morgenthau, Politics among Nations. Quoted in Frei, "Politics among Nations," 64 .

${ }^{20}$ On realism, see Bew, Realpolitik; Craig, Glimmer of a New Leviathan; Guilhot, Invention of International Relations Theory; and Freedman, Future of War.

\author{
${ }^{21}$ Quoted in Price, Cold War Anthropol- \\ ogy, 4 . \\ ${ }^{22}$ Greenberg, Weimar Century, chap. 5. \\ ${ }^{23}$ Desch, Cult of the Irrelevant, 81. \\ ${ }^{24}$ Baratta, "International History," 382.
}

${ }^{25}$ Quoted in Baratta, "International Federalist Movement," 346.

\footnotetext{
${ }^{26}$ Angell, "Sociology and the World Crisis," 751.
} 
important work to do on the international stage. But his agenda for the sociological study of war was among the Cold War's early intellectual casualties. In his presidential address, he laid out a research agenda for sociologists, calling upon them to apply their expertise in social structures, communications, and attitudes to identify techniques and approaches that would improve allegiance to the United Nations. But his call went almost entirely unheeded. So too did C. Wright Mills' 1958 The Causes of World War Three. The impassioned tract called upon sociologists to interrogate the role that the power elite played in creating conflicts, but it quickly went out of print. ${ }^{27}$ Between 1945 and 1990, only 4 of 6,500 articles published in major sociology journals addressed nuclear war. ${ }^{28}$

With the deepening of the Cold War, many sociologists turned away from the study of war as a social problem. The few sociologists who continued to focus on war turned to investigating the military as a social organization. Largely funded by the armed services, the small subfield of military sociology coalesced in the 1950s around studies of military occupations, civil-military relations, and the role the military played in development. With international cooperation labeled subversive, the social problems approach to war commanded comparatively little social scientific attention. ${ }^{29}$ Less than a decade after Wright's Study of War, the social problems approach was waning.

\subsection{War as Security Problem}

Instead of fostering international understanding, many social scientists took on the urgent project of shoring up American power and strengthening national security. From the end of World War II through the late 1960s, social scientists pursued a variety of intellectual projects aligned with the conviction that the nation was locked in an existential struggle with the Soviets. In the process, they redefined war as a security problem and applied themselves to the maintenance of American national security and international hegemony. This project was, perhaps, less audacious than the pursuit of permanent peace through international understanding. But it was still ambitious. Scholars asked what the next war might be like, if and when it benefited American national interests to wage war, and how statesmen could effectively wield the threat of force against their enemies in order to strengthen American power without triggering violence.

Morgenthau's realist international relations theory, with its emphasis on contextual and qualitative analysis, occupied one influential vein of this scholarship, but other approaches both complementary and competing flourished, including game theory and politicalmilitary gaming. As decolonization reshaped geopolitics, social
${ }^{27}$ Mills, Causes of World War Three. See Kurtz, "War and Peace," 76.

${ }^{28}$ Kurtz, "War and Peace," 65.

${ }^{29}$ Kurtz, "War and Peace." 
scientists also deployed new categories of conflict, like unconventional warfare, and developed new approaches for the economic and political modernization of new nations. These intellectual trends are the subject of the first half of this section. The section's second half takes up a parallel and complementary pursuit: the development of largely statistical and quantitative studies of war driven by the values of the behavioral revolution, which sought to displace the theorizing of realists like Morgenthau with empirically grounded, predictive tools to manage war.

Each of these intellectual traditions promised to manage wars of all sorts rationally. With this promise, social scientists attracted generous government funding that had the potential to vault them to the forefront of US security policy. In the interwar period, the social scientific study of war had been supported largely by foundation grants. Military and intelligence agencies dramatically expanded their financial support for social science from the 1940s to the 1960s. Intelligence budgets are notoriously difficult to document, but in the early 1960s, the military's social science budget was \$15 millionmore than its annual budget for $R \& D$ in all scientific and engineering fields in the decade prior to World War II..$^{30}$ By the late 1960s, at the height of social scientific involvement in the Vietnam War, the Defense Department spent $\$ 40$ million a year on social science. ${ }^{31}$ The period between the end of World War II and the Vietnam War was the heyday of the social science of war-an era of diverse research agendas, full coffers, and institutional expansion.

Yet, this section shows that despite the dominance of national security funds and framings, the social problems-orientation toward war was not fully eclipsed at mid-century. A handful of influential scholars, including Angell and Wright, kept the commitment to peace through social science alive via a new interdisciplinary effort dubbed peace research. That these researchers coexisted and even collaborated with scholars dedicated to war's rational management signals the intellectual eclecticism in the mid-century study of war.
${ }^{30}$ Herman, Romance of American Psychology, 128-29.

${ }^{31}$ Price, Cold War Anthropology, 45-51.

10.2.1 Nuclear Games and Modernizing Nations: Managing War at RAND, MIT, and SORO

The decade after World War II saw unprecedented institutional and intellectual growth in the social science of war. RAND, created by the Army Air Force in 1946 and staffed by civilian researchers, was tasked with providing scientifically grounded recommendations for "preferred methods, techniques, and instrumentalities" for conducting air warfare in the nuclear age. ${ }^{32}$ It quickly became known for pioneering novel approaches to war, among them game theory,

${ }^{32}$ Quoted in Desch, Cult of the Irrelevant, 125 . 
psychological warfare, and political-military gaming.

RAND's mathematicians were among the first to theorize war as a game. A 1948 report explained that war "is similar to a game of strategy between opposing players." Each seeks to "maximize some function, such as defense," yet neither controls all of the variables. ${ }^{33}$ Game theory failed to bear strategic or tactical fruit in its formalist mathematical form. But it was a powerful heuristic device. Bernard Brodie, a RAND strategist who worked on A Study of War while a PhD student at the University of Chicago, explained that, when it came to strategy, "What matters is the spirit of the gaming principle, the constant reminder that in war we shall be dealing with an opponent who will react to our moves and to whom we must react." 34 Game theory stressed the mental and communicative, rather than the martial, elements of conflict. As economist and RAND consultant Thomas Schelling explained, war was not merely a "contest of strength," but one of "nerve and risk-taking." 35 It was "always a bargaining process" dominated by "threats and proposals, counterproposals and counterthreats, offers and assurances." 36

By treating war as an interaction between players, game theory encouraged scholars and policymakers to treat war as a problem of rational, efficient, expert decision-making. Amid a cultural backdrop of books and films like Red Alert (1958), Fail Safe (1964), and Dr. Strangelove (1964), in which unanticipated mistakes and human irrationality threaten nuclear war, strategists offered decision protocols that made choice more bureaucratic, more formal, and thus less dangerous. Schelling argued that game theory could guide both the "rational calculator in full control of his faculties" as well as the "nervous hotheaded frightened desperate decision that might be precipitated at the peak of a crisis, that might be the result of an accident or false alarm, that might be engineered by an act of mischief."37

During the 1950s and 1960s, American policymakers drew regularly on game theory to justify policies like mutually assured destruction and the American air war in Vietnam. In the hands of game theorists, war was decidedly not a social problem. Rather than an abhorrent cause of human suffering, it was a conceptually bloodless activity, a contest between two faceless choosers whose most relevant characteristics were the national interests they desired to maximize and their ability to follow a set of social-scientifically derived decision protocols. As Schelling wrote, "if we can talk about wars in which tens of millions could be killed thoughtlessly, we ought to be able to talk about wars in which hundreds of thousands might be killed thoughtfully." ${ }^{8}$ Far from cooperative, the very production of rational decisions seemed to require the eradication of social instincts like cooperation or empathy. 39
${ }^{33}$ Quoted in Leonard, Von Neumann, Morgenstern, and the Creation of Game Theory, 309.

${ }^{34}$ Quoted in Ayson, Thomas Schelling and the Nuclear Age, 130.

${ }^{35}$ Quoted in Amadae, Prisoners of Reason, 87 .

${ }^{36}$ Quoted in Kuklick, Blind Oracles, 138.

${ }^{37}$ Quoted in Freedman, The Future of War, 8o.

\footnotetext{
${ }^{38}$ Quoted in Desch, Cult of the Irrelevant, 165.

${ }^{39}$ Amadae, Prisoners of Reason.
} 
Game theory's prescriptive embrace of preference maximization bears more than a passing resemblance to contemporary economics. But game- theoretic approaches to war were not imported from economics. Rather, they grew out of interdisciplinary connections between the variety of scholars-mathematicians like John von Neumann, economists like Oskar Morgenstern and Schelling, and political scientists like Brodie - who worried about national survival in the nuclear age. Not until the 1970 and 1980 s did game theory make significant inroads into economics..$^{40}$ As Robert Leonard has shown, war was too simple of an economic problem to attract sustained interest from the economics community after World War II. $4^{1}$

While game theory is perhaps RAND's best-known intellectual product, its social scientists developed a number of other approaches to war. Guided by Weimar émigré and realist thinker Hans Speier, its Social Science Division (SSD) examined "the identification, measurement and control of factors important in (1) the occurrence of war, and (2) the winning of war if it should occur." 42 This mission was managerial in nature, aimed at advising elite military and civilian policymakers who confronted the specter of war.

SSD analysts studied psychological warfare, devising programs to destabilize enemy propaganda. But its political-military game-a simulation of decision-making during crisis—garnered the division more significant policy attention in the 1950s and early 1960s. Concerned that game theory failed to capture the real-world contingenciesindividual and group psychology, history, politics, culture, stress, and other qualitative factors - that impacted crisis decision-making, Speier and fellow sociologist Herbert Goldhamer offered the politicalmilitary game as a qualitative, experiential technique for producing knowledge about war. The game placed human players in scenarios where they took on the roles and responsibilities of policymakers facing the onset of hypothetical or real-life conflicts. In one 1955 game, Germany (Speier), the United States (Goldhamer), the Soviet Union and France (sociologist Nathan Leites), and Great Britain (historian H. A. Deweerd) played out US security policy toward Western Europe. The Pentagon adopted the technique. In 1964, its Joint War Games Agency brought together high-ranking officials, including McGeorge Bundy, Curtis LeMay, and members of the Joint Chiefs of Staff, to simulate the escalation of the Vietnam War in an effort to assess strategic alternatives. While Speier and Goldhamer had hoped their method would provide scientific knowledge about decisionmaking, by 1959 they concluded that the technique held little scientific promise. Instead, the simulations were better for assessing specific strategies and training decision-makers. 43
${ }^{40}$ Amadae, Rationalizing Capitalist Democracy; Erickson, World the Game Theorists Made; and Weintraub, Toward a History of Game Theory.

${ }^{41}$ Leonard, "War as a 'Simple Economic Problem.'"

${ }^{42}$ Quoted in Leonard, Von Neumann, Morgenstern, and the Creation of Game Theory, 303. On Speier and the SSD generally, see Bessner, Democracy in Exile.
${ }^{43}$ Bessner, "Weimar Social Science in Cold War America." 
RAND was only one of a number of new institutes created after World War II to study and manage war. At MIT, a Ford Foundation grant and an infusion of secret CIA funds birthed the Center for International Studies (CIS) in 1952.44 Its original charter instructed researchers to develop methods, targets, and messages for psychological warfare campaigns against the Soviet Union and its satellites. But the center soon expanded the intellectual terrain of its war-related research. In a secret memo justifying the university's clandestine relationship with the CIA, MIT's provost explained that the "long pull" against communism made it "imperative that we mobilize our resources for research in the broad field of political warfare," just as physical scientists had mobilized to support conventional warfighting. 45 As decolonization yielded new nations, social scientists expanded their purview to nation-building itself. At MIT's CIS, some of the leading social scientists of the postwar generation-including economic historian Walt Rostow, political scientist Gabriel Almond, and sociologist Daniel Lerner-devised theories of political and economic modernization meant to guide new nations through the development process without succumbing to communism. An interdisciplinary school of thought, modernization theory "posited the existence of a common and essential pattern of 'development, defined by progress in technology, military and bureaucratic institutions, and the political and social structure.' "'46 The problems that ostensibly accompanied modernization could, moreover, lead to types of violence over which social scientists claimed expertise in the 1950s and 1960s: guerrilla warfare, insurgency, civil war, and revolution.

The sheer variety of conflict types justified the creation of yet another institution: the Army's Special Operations Research Office (SORO), created in 1956 and housed at American University in Washington, DC. SORO mobilized political scientists, anthropologists, sociologists, social psychologists, and former military officials to build a social science of "unconventional war"-yet another term of art. They marshaled historical and quantitative evidence to identify the political, economic, and psychological variables that correlated with violent revolution; fielded surveys to identify the psychological traits that Latin Americans ostensibly found attractive in their leaders; and sought the organizational factors that facilitated US nation-building efforts overseas. 47

By claiming to facilitate the alleviation of human suffering, SORO and MIT's CIS appeared to draw on the social problems approach. At a 1962 conference, SORO's associate director, psychologist William Lybrand, explained to an audience of defense officials and social scientists that social knowledge would help the military "create internal conditions and encourage political, social, and economic systems
${ }^{44}$ Pooley, "Remobilization of the Propaganda," 25 and Simpson, Science of Coercion, 81-82. On the history of CIS, see Gilman, Mandarins of the Future, chap. 5 .

${ }^{45}$ Quoted in Desch, Cult of the Irrelevant, 92.

${ }^{46}$ Gilman, Mandarins of the Future, 3.

47 Rohde, Armed with Expertise. 
which remove hunger, disease, poverty, oppression, and other sources of discontent" from developing nations. ${ }^{8}$ Instead of producing research geared toward public-facing social and educational campaigns to eliminate war, however, modernization theorists and scholars of unconventional war encouraged political and military interventions that were sometimes clandestine and often imposed by elites. 49 At SORO and MIT, as at RAND, the reduction of human suffering and the development of democratic world communities-a centerpiece of the social problems approach-took a backseat to American national security.

\subsubsection{Building a Behavioral Science of War}

The MIT and SORO researchers who sought scientifically validated knowledge about conflict were influenced by the behavioral revolution which swept through the social sciences in the 1950 ..$^{\circ}$ Behavioralism's advocates insisted that social science be "modeled after the methodological assumptions of the natural sciences." Instead of preceding empirical research, theory should follow from the collection of empirical observations-ideally those that could be measured, aggregated, and expressed quantitatively. Only when scholars developed a generalizable body of "tested propositions" that could be applied to social behaviors across time and space could social science earn its rightful status as a science. ${ }^{11}$

Behavioralism shaped a number of intellectual projects related to war in the 1950s and 1960s. The movement reached its apex in a research tradition that went by a variety of names as it emerged in the 1950s and 1960s, including conflict resolution, peace studies, quantitative international politics, or-most simply and aspirationally - international relations. This tradition came to be dominated by international relations experts, but in its early years included political psychologists, sociologists, and a handful of economists, all of whom were united by their devotion to placing the study of war on a behavioral-scientific footing. MIT political scientist Karl Deutsch, a leading figure in the movement, explained that this research had three goals: "to identify generally those conflict situations and states which are likely to lead to war; to evaluate particular conflict situations and the probable lines along which they are likely to develop if left to themselves; and to suggest further possible techniques for controlling or containing such conflict situations so as to prevent them from breaking out into war." 52

As Deutsch's description implies, the behavioralist study of war promised to manage conflict by developing quantitative indicators and other predictive tools that could alert policymakers to the onset
${ }^{48}$ Quoted in Rohde, Armed with Expertise, 34 .

${ }^{49}$ Latham, Right Kind of Revolution, chap. 5 .
${ }^{50}$ Though "behavioralism" and the "behavioral revolution" were the common labels within political science, the broader movement inclusive of the other social sciences (economics excepted) typically used the sibling "behavioral sciences" phrase. The terms are used interchangeably here.

${ }^{51}$ Quoted in Gunnell, Descent of Political Theory, 255, 214.
${ }^{52}$ Quoted in McClelland, "Acute International Crisis," 189. 
of war and enable them to respond rationally. Military officials were intrigued. In the early 1960s, the Navy contracted with political scientists and political psychologists who sought the signs of emerging conflict in the communications that passed between nations. 53 The Advanced Research Projects Agency (ARPA) generously bankrolled a variety of efforts to build quantitative measures and models of international affairs beginning in the mid-196os. It funded Yale's Political Data Program, which published the World Handbook of Political and Social Indicators, a volume that included "hard data" on everything from land distribution to riots to voter turnout in 130 countries. 54 And the agency supported University of Hawaii political scientist R. J. Rummel (who sought signs of war in the covariance between adversary nations' population sizes, economic power, geographic proximity, and degrees of press freedom, among other attributes) 55 and University of Michigan political scientist Raymond Tanter (who created a computer infrastructure for preserving and sharing international conflict datasets across institutions). ${ }^{56}$ Such research was not confined to defense-supported scholars. At the University of Michigan, J. David Singer launched his Correlates of War (COW) project in 1963, which sought conflict indicators in statistical tests of the "frequency, participants, duration, and battle deaths of all interstate wars" since the Congress of Vienna, the event that international relations scholars agreed established the modern state system. 57

With its emphasis on prediction, this work embraced the era's managerial orientation toward conflict. Even so, some of its most prominent figures maintained a glimmer of the old social problems frame. Deutsch explained that his systematic quest "to understand war and peace as social processes, with the analytic tools of social science" was directed at "the permanent establishment of peace." 58 That Deutsch's description paralleled some of Quincy Wright's language in A Study of War was no accident. Deutsch, Singer, and their intellectual kin traced their ancestry to the University of Chicago scholar. They did not espouse Wright's Deweyan vision of peace through international understanding, however. Rather, they viewed Wright as a founder of the quantitative, empirical study of war. $A$ Study of War, after all, had compiled hundreds of pages of quantitative descriptions of conflict. According to Singer, the text proved that "mathematics could help to capture international interactions, statistics could reveal the extent to which certain conditions and events can and do rise and fall together," allowing scholars to progress "from the anecdotal and impressionistic to the operational and reproducible."59 Wright's effort to find causal relationships between a people's "warlikeness" and a host of variables-population density, energy production, average annual temperature, social organizational
${ }^{53}$ Desch, Cult of the Irrelevant, 97-98.

${ }^{54}$ Banks, "Review of the World Handbook"; Russett et al., World Handbook of Political and Social Indicators; and Taylor, Hudson, and Russett, World Handbook of Political and Social Indicators.

${ }_{55}$ Young et al., Utilization of ARPA-

Supported Research, 50-54.

${ }^{56}$ Tanter, Policy Relevance of Models.

${ }^{57}$ Morrow et al., "J. David Singer," 591 and Singer and Small, Wages of War.

${ }^{58}$ Deutsch, “In Memorium," 107.
59 Singer, "Correlates of War," 450. See also Bueno de Mesquita, "Game Theory, Political Economy, and the Evolving Study." 
style, number of battlefield honors or casualties, to name just a fewwas worthy of emulation. ${ }^{60}$

A handful of influential scholars sought to preserve and extend Wright's normative commitment to peace, and not just his methodological approach. Calling themselves peace researchers, they tended to come from disciplines other than political science. Angell, the sociologist who advocated international understanding as the key to overcoming war, helped create the Center for Research on Conflict Resolution (CRCR) at the University of Michigan in 1959; he directed the center until 1964. ${ }^{61}$ CRCR economist Kenneth Boulding, social psychologist Herbert Kelman, and mathematical biologist Anatol Rapoport argued that social science could build peace by attending to the psychological, social, and especially cooperative elements of human affairs. Boulding, a Quaker pacifist, stressed the importance of "love, affection, empathy, and a community of feeling" as critical to understanding war and peace. He lamented that most social science "forgets the ills of society and becomes deaf to the cry of the hungry and blind to the misery of the oppressed." 62 For Boulding, the social scientific study of war should be rooted in moral as well as scientific values. He called on social scientists to build an "intellectual chassis" strong enough to "support the moral engine" which could drive "the abolition of war." 63

But the CRCR was a broad intellectual tent. It included Singerwho self-identified as a peace studies scholar although he only paid lip-service to eradicating war-among its faculty. Perhaps more revealing of its intellectual and normative breadth, CRCR was the original home of the JCR. Founded in 1957 to create a venue for interdisciplinary research that strengthened the study of war "through quantification," the journal's contributors were united in their desire to substitute social science - preferably but not exclusively quantitative-for the unscientific advice of "lawyers, merchants, diplomatists, and military men." 64

The eclectic scholarship in JCR's pages demonstrates that the peace researchers' social problems frame coexisted with managerial approaches that eschewed any form of moral advocacy. JCR also showcased some of the methodological continuities between social problems and managerial approaches to war. The journal's inaugural issue included an article in which Wright advocated for peace via a thoroughgoing program of psychological, social, and political reforms that impressed upon the world's citizens their global kinship and interdependence. Wright called upon international organizations to create a "world intelligence center" that would "enlighten the public by presenting and analyzing factual material indicating the changing atmosphere of world opinion, the changing condition
${ }^{60}$ Wright, Study of War. The peace research community also traced its lineage to Lewis Fry Richardson, a British mathematician, meteorologist, and pacifist who spent his free time in the 1920 and 1930 marshaling quantitative evidence-from the rates of arms purchases and the lengths of shared borders to the similarities and differences among nations' cultures and religions-to perform statistical analyses in a search for the causes of war. On Richardson, see Erickson, World the Game Theorists Made, 186.

${ }^{61}$ Harty and Modell, "First Conflict Resolution Movement," 734.

${ }^{62}$ Quoted in Fontaine, "Stabilizing American Society," 246, 247.

${ }^{63}$ Quoted in Freedman, Future of War, 111.

\footnotetext{
${ }^{64}$ Quoted in Erickson, World the Game Theorists Made, 187. On the preference for quantification, see Harty and Modell, "First Conflict Resolution Movement," 731.
} 
of world politics, and the alternatives available and the probable consequences of adopting each." 65

Instead of battling over the status of war as a social or managerial problem, the scholars who published in the JCR united against their realist interlocutors. Articles by Morgenthau and other realists were unwelcome; advocates of the behavioral science of war scorned realism's pessimistic rejection of science and quantitative empiricism. Singer disparaged realism as mere "speculation and impression."66 Rapoport objected to its dark conclusions. He wrote that realists "translated the game of strategy (where men may engage in ruthless and cunning to their heart's content because it is only a game) into a plan of genocidal orgies, and we call the resulting nightmare 'realism. " "67 Not surprisingly, realists pushed back, attacking quantitative and empirically minded scholars for their "fetish for measurement" and misguided faith that war could be controlled through science. ${ }^{68}$ This so-called second great debate in international relations pitted "historically minded, traditional realists" against "advocates of a sciency approach to politics," including quantitative and formal game-theoretic methods. ${ }^{69}$

Despite this methodological disagreement, realists and behavioralists coexisted in the same institutions, a demonstration of the intellectual flexibility that fueled scholarship in this period. RAND's SSD alone was capacious enough to accommodate the behaviorally minded psychologist John L. Kennedy, who believed in mathematically modeling human behavior, and political scientist Paul Keckskemeti, who vociferously rejected the claim that "rigorously quantitative terms" held the key to understanding human behavior. $7^{0}$ Similarly, scholars who embraced game theory could also work comfortably with qualitative and realist approaches. Schelling, best known for his game-theoretic understanding of war, directed a political-military game at Camp David in 1958 whose players included high-level Washington policy figures and scholars such as McGeorge Bundy, Alain Enthoven, Carl Kaysen, Henry Kissinger, and Walt Rostow. $7^{1}$

The sometimes competing, sometimes overlapping approaches to war at RAND, MIT, and elsewhere reflected a number of shared convictions. For scholars of modernization and unconventional warfare, military-political gamers and game theorists, realists and behavioralists, war was primarily a problem of national security and defense. Funded generously by national security agencies, the study of war was the ambit of scholarly and policy elites rather than the concern of international publics. In the heady period between the end of World War II and the nation's full-scale mobilization in Vietnam, war captivated scholars and government officials. It was just too good
${ }^{65}$ Wright, "Project for a World Intelligence Center," 94.

${ }^{66}$ Singer, "Editor's Introduction," 1.

${ }^{67}$ Quoted in Tomás Rangil, "Finding Patrons for Peace Psychology," 105.

${ }^{68}$ Quoted in Ruzicka, "A Fetish for Measurement?" 368. See also Guilhot, After the Enlightenment.

${ }^{69}$ Guilhot, After the Enlightenment, 153.

$7^{70}$ Quoted in Bessner, Democracy in Exile, 213.

${ }^{71}$ Bessner, Democracy in Exile, 224. 
to give up. As one social scientist explained in 1970, scholars generally agreed that "war is probably not an a priori evil; wars often accomplish very desirable goals, particularly if they are undertaken to remedy injustice." Instead of eradicating war altogether, the scholarly community was "only interested in reducing wars which emerge from less lofty motives."72

An elite minority of scholars-including Wright and Angell disagreed. Under the guise of peace research, a handful of social scientists from a variety of disciplines continued to insist that war was a social problem that demanded international action guided by social research. But it would be a bloody conflict in Southeast Asia, not the pleas of peace researchers, that would ultimately kill off at least some managerial social scientific approaches to war.

\subsection{War as the Territory of International Relations}

The Vietnam War was a proving ground for social scientists' managerial approaches to war. In the second half of the 1960s, anthropologist Gerald Hickey put the study of unconventional war to the test by advising the US armed forces how to conduct its military and counterinsurgency programs for ethnic groups living in the South Vietnamese Highlands. RAND political scientists interviewed POWs and defectors seeking an answer to Robert McNamara's query: "Who are the Viet Cong and what makes them tick?"73 And Sovietologist Leon Gouré joined Schelling in arguing that coercive bargaining in the form of escalated bombing campaigns would quash the insurgency in the South and bring North Vietnam to its knees. ${ }^{74}$

Social scientists' advice failed to deliver a rationally managed war. Gouré's coercive bargaining produced dead bodies, but not victory. 75 Modernization, counterinsurgency, and counterrevolutionary projects failed to convert Vietnamese hearts and minds to the American cause. While some of these failures seemed to indict the behavioral-scientific approach, realist theorist Morgenthau blamed Washington, not social science, for US failures. By escalating the conflict, he argued, policymakers had violated realism's most fundamental tenet; they traded "sober calculations of power and self- interest in favor of abstract moral and ideological principles."76

Instead of solving the problem of war, social science appeared to have helped birth a new social problem - the domination of American intellectual, political, and social life by military values and concerns. Antiwar activists and even some policymakers attacked the alliance of scholarship and national security that, they argued, fostered needless American bellicosity. On Capitol Hill, J. William Fulbright, chair of the Senate Foreign Relations Committee, argued that the mil-
${ }^{72}$ Haas, "Three Approaches to the Study of War," 44 .

${ }^{73}$ Elliot, RAND in Southeast Asia, 25-28, 53 .

74 Weinberger, Imagineers of War, 174-75 and Desch, Cult of the Irrelevant, 171-74.

75 Tomás Rangil, "Rebellions across the (Rice) Fields."
${ }^{76}$ Christoph Frei, quoted in Desch, Cult of the Irrelevant, 200. 
itary had used social science as a means to assume "responsibility for making political judgments," hardly its proper jurisdiction, "all over the world." Allowing military-funded social science research to continue, he argued, would only lead "to more Vietnams."77 Congress slashed the military's social research budget in 1969.

On campuses across the country, student activists attacked militaryfunded social research for its corrosive impact on intellectual and public life. At American University, home to the Army's SORO, students labeled the university a "part of the interlocking corporate power elite - the industrial (exploitation)-military (kill for freedom and/or money) —education (indoctrination) complex."78 At MIT, student activists held a mock trial of CIS faculty and found them guilty of "crimes against humanity."79 And at Columbia University, over a thousand protesters called upon the administration to sever the university's ties with Defense Department research institutes. Antiwar intellectuals, including linguist Noam Chomsky and anthropologist Kathleen Gough, referred to scholars who worked on national security problems as "henchmen of the military-industrial complex."80

Although activists and policymakers charged security-funded social science with creating a social problem of its own, they did not call upon social scientists to reframe war as a social problem deserving study in its own right. Instead, they demanded institutional and intellectual disinvestment from war altogether. Military officials, burned by the empty promises of their social science advisers, also reduced their support for social research. By the early 1970s, the landscape of the social science of war shifted. American University and the Army cut their ties in 1969, leading to SORO's removal from campus. Modernization theory crumbled under a withering critique of its teleological adherence to unilinear narratives of human progress. ${ }^{81}$ RAND analysts continued to work on war-related problems, but the twin pressures of reduced military investment and scholarly skepticism of war-related work drove its leadership to pursue more projects in the domestic sector. ${ }^{82}$

In the wake of these shifts, war-related social science lost much of its disciplinary diversity. Many anthropologists called upon their discipline to abandon the study of war and drop ties to the military to protect their field from the taint of martial values. With the decline of modernization theory and military investments in political and unconventional warfare, sociologists and political psychologists turned away from the study of war too. 83

The interdisciplinary field of peace research, perhaps counterintuitively, also failed to gain traction. Instead of reviving the study of war as a social problem, the CRCR ran out of funding. By 1970, Boulding, Rapoport, and Kelman had all departed the University of
77 Quoted in Rohde, Armed with Expertise, 110, 115.

${ }^{78}$ Quoted in Rohde, Armed with Expertise, 113 .

${ }^{79}$ Quoted in Oren, Our Enemies and Us, 152.

${ }^{80}$ Quoted in Rohde, Armed with Expertise, 120, 99-100.

${ }^{81}$ Gilman, Mandarins of the Future.

${ }^{82}$ Rohde, Armed with Expertise.

${ }^{8}$ Rohde, Armed with Expertise. 
Michigan. The university abolished the center in 1971 and the JCR relocated to Yale, home of the behavioralist World Handbook of Political and Social Indicators. ${ }^{84}$ Over the next decade, the journal's commitment to formal and behavioral methods like game theory and statistical analysis of quantitative empirical data continued. Contributions from sociologists and psychologists declined, and political scientists came to make up the majority of contributions. Game theory's star rose in the 1970s; the study of games rose from 8 percent to 25 percent of $J C R^{\prime}$ s contents within a few years of its transition to Yale. ${ }^{85}$ While political scientists dedicated to formal and quantitative studies of war continued to refer to themselves as peace researchers, the pacifist school of peace studies was pushed even further to the margins of social science; its affiliation with peace activism left it chronically underfunded and intellectually suspect among advocates of scientific and formalist approaches. ${ }^{86}$

Political science took center stage in the 1970s in part because the discipline remained sanguine about working on security projects. The American Political Science Association weathered an attempted insurrection in 1968 and 1969 by representatives of the Caucus for a New Political Science, who accused their colleagues of "merely describ[ing] and perpetuat[ing] the social and political status quo." 87 The Caucus fielded Morgenthau - a staunch critic of both the Vietnam War and the scientistic efforts of behavioralist scholars - as their presidential candidate. But he was defeated and the Caucus was quickly relegated to the edges of the profession. ${ }^{88}$ Even so, Morgenthau's status in the Caucus indicated the continued salience of realism in international relations, even amidst the behavioralist tide.

Instead of joining the Caucus' political defection, many political scientists argued that the failures of social science in Vietnam demonstrated the need for more-not less-research on the science of war. Political scientist and onetime ARPA program manager Raymond Tanter explained that social scientists had treated the war as a laboratory, but they had done so sloppily. Social scientists and their patrons had identified a variety of social variables to manipulate, from the psychology of Vietnamese peasants to the locations of secure hamlets. But they had no scientific basis to support the hypothesis that their interventions would sway the population toward the South Vietnamese government. The quantitative study of war, Tanter concluded, would provide hard evidence of cause and effect-a "scientific" basis for decision-making. ${ }^{89}$

DARPA (renamed the Defense Advanced Research Projects Agency in the early 1970s) remained optimistic that quantitative studies of war could provide tools to rationally manage conflict. While most federal funding for war-related social science declined precipitously
${ }^{84}$ See Erickson, World the Game Theorists Made; Tomás Rangil, "Finding Patrons for Peace Psychology"; and Harty and Modell, "First Conflict Resolution Movement."

${ }^{85}$ Harty and Modell, "First Conflict Resolution Movement," 738 .

${ }^{86}$ Kurtz, "War and Peace."

${ }^{87}$ Quoted in Oren, Our Enemies and Us, 162.

${ }^{88}$ Oren, Our Enemies and Us, 162-63.

${ }^{89}$ Tanter, Policy Relevance of Models, 1. 
after 1968, DARPA continued to support research that sought validated predictive indicators of conflict through the $1970 \mathrm{0.} .9^{\circ}$ This investment was aided by the conviction, shared among behavioralists since the 1950s, that scholarship's purpose was "not to change the world, but to assist authorities in getting a firmer grip on the existing social order." 91 By the 1970s, scholars who mined quantitative data on war for statistical correlations and laws no longer identified themselves as behavioralists, but they maintained much of behavioralism's ideology. Behavioralism had itself played an important role in moving social science away from the study of social problems. The social problems frame's normative embrace of peace appeared suspect in a climate of anticommunism; but normative commitments to military action, too, were open to critique during and after the Vietnam War. As an ostensibly value-neutral pursuit, the quantitative approach to conflict could offer political safe haven for researchers and their national security patrons in the 1970 s.

Unfortunately for researchers and their patrons, however, this work bore little predictive fruit. By the mid-1970s, R. J. Rummel's Dimensionality of Nations had amassed a catalogue of rejected hypotheses. Another seemingly promising DARPA-funded effort, the World Event-Interaction System, fared only slightly better. Created by onetime CRCR affiliate Charles McClelland, it was a computerized catalogue of cooperative and threatening interactions between the world's 160-plus nations, containing over 120,000 event entries by the end of the 1970s. But a multimillion-dollar DARPA project to operationalize the database as a real-time crisis predictor for the US European Command and Ronald Reagan's national security staff in the White House ended in failure in the early 1980s. ${ }^{92}$

Although their quarry eluded them, researchers did not conclude that their efforts were misguided. Instead, they doubled down on their pursuit of statistically validated knowledge about war. For Singer - one of the only CRCR affiliates to remain at Michigan after the Center closed-the painstaking work of amassing datasets and applying statistical tests to conflict became an end in itself. Singer directed the COW project until his retirement in 2002. As he added new datasets and tested new hypotheses about war's causes, he trained a generation of international relations experts in quantitative and statistical techniques. COW outlived Singer; his students continue to seek war's definitive correlates. 93

Even as they fully embraced their policy purpose, however, political scientists worried that their policy relevance was waning. Like other fields shaped by the behavioral revolution of the 1950s and 1960s, the study of war increasingly took the form of arcane discussions of statistical methodology and causal rigor. Between behavioral-
${ }^{90}$ Rohde, "Pax Technologica."

${ }^{91}$ Parenti, "Patricians, Professionals, and Political Science," 502.

${ }_{92}$ Rohde, "Pax Technologica."

\footnotetext{
93 "Correlates of War Project," www.correlatesofwar.org. See also Suzuki, Krause, and Singer, "Correlates of War Project."
} 
ism and the searing experience of Vietnam, many researchers turned inward, away from policy relevance. ${ }^{94}$ The military's eventual disenchantment with the social science of war bore some of the blame for this insularity. The Reagan administration slashed funding for social science broadly in the early 1980s. But by this time, the managerial approach to conflict was firmly entrenched in political science departments and ostensibly multidisciplinary journals like JCR, International Security (first published 1976), and Conflict Management and Peace Science (first published as Journal of Peace Science in 1973 and renamed in 1980).

By the 1980s, no single political science approach-game-theoretic, quantitative, or realist-dominated the political scientific study of war. While realists and behavioralists had spilled much ink in the 1950 and 1960s debating whether war could be approached scientifically, the next generation of scholars sought to reconcile the two camps. This new neorealist school of international relations gave pride of place to the role of power in international politics, as Morgenthau had. But it also embraced game-theoretic, quantitative, and other formalist efforts to locate the causes of conflict. Despite the vitriolic debates between realists and advocates of the ostensibly "scientific" study of war embodied in the COW project and formal game theory, international relations offered a broad enough intellectual tent to contain them all.95

\subsection{Conclusion}

In their 1955 textbook The Sociology of Social Problems, Paul B. Horton and Gerald R. Leslie reflected on Western nations' hypocrisy when it came to war. Although Westerners professed to love peace, they "express pride over never having lost a war, build countless statues of military heroes, describe history in terms of battles and wars, and form nonintervention pacts with other nations - strange behaviors for peaceful peoples." 96

A generation earlier, many social scientists held out hope that they could eradicate Americans' fixation on war. Between World War I and World War II, efforts to rein in human violence and foster international understanding yielded interdisciplinary and internationalist projects. But instead of cementing the perceived need for peace, nuclear proliferation, deepening Cold War tensions, and the growth of a national security state hungry for actionable knowledge, inspired social scientists to create a managerial approach to war. Their project was aided in no small part by the lessons of the European crisis of democracy in the 1930 and 1940s, and the fear that human irrationality and nuclear arsenals posed a cataclysmic risk to humanity.
${ }^{94}$ For example, Azar and Ben-Dak, Theory and Practice of Events Research and Singer and Small, Wages of War. On the tendency of behavioralism to retreat from policy, see Dryzek, "Revolutions without Enemies," 490 and Gunnell, Descent of Political Theory.
${ }^{95}$ Bessner and Guilhot, "How Realism Waltzed Off" and Guilhot, After the Enlightenment, chaps. 5-6.
${ }^{96}$ Horton and Leslie, Sociology of Social Problems, 462-63. 
Perhaps counterintuitively, social scientists viewed human irrationality as more amenable to containment than nuclear weapons. Amid nuclear proliferation and deep enmity between the United States and the Soviet Union, social scientists partnered with government patrons in an effort to maintain and expand American dominance in the face of its enemies. Between the late 1940s and the late 1960s, social scientists worked at new research institutes and devised new methods and theories for managing war efficiently and rationally.

In 1955, Horton and Leslie confronted a "frightening prospect": "war is deeply rooted in the culture of modern nations ... only major alterations in that culture offer much hope for its elimination." 97 By the end of the 1970s, the same could be said of international relations. In the wake of the behavioral revolution and the Vietnam War, anthropologists, sociologists, and psychologists retreated from the study of war. This remains true today. Aside from the largely marginalized field of peace studies, war-whether framed as a social or security problem -is no longer a central concern for other social science disciplines. Nor is peace. In academic and policy circles, the suggestion that social science can eliminate war is treated as nothing short of preposterous.

While these shifts may reflect a laudable reduction in the hubris - not to mention hypocrisy - of the social science of war, they also reflect the dramatic hold that national security has over political thought and practice. While methodological similarities tie the interwar traditions of Morgenthau, Wright, and others to contemporary neorealism, the ideological goals that motivated the social problems' framing have faded away. Few mainstream international relations scholars or practitioners see permanent peace as a pragmatic pursuit. The study of war continues to be framed in the context of security, statecraft, and the management of conflict in ways that accord with the political status quo. Without a powerful political, financial, and intellectual push in a different direction, the conviction that social science - and political science in particular-is a valuable managerial tool for violence as an instrument of statecraft is here to stay.

\section{Bibliography}

Amadae, S. M. Rationalizing Capitalist Democracy: The Cold War Origins of Rational Choice Liberalism. Chicago: University of Chicago Press, 2003.

Amadae, S. M. Prisoners of Reason: Game Theory and Neoliberal Political Economy. New York: Cambridge University Press, 2015.

Angell, Robert C. "Sociology and the World Crisis." American Socio-
${ }^{97}$ Horton and Leslie, Sociology of Social Problems, 462-63. 
logical Review 16, no. 6 (1951): 749-57.

Ayson, Robert. Thomas Schelling and the Nuclear Age: Strategy as Social Science. London: Frank Cass, 2004.

Azar, Edward E., and Joseph D. Ben-Dak, eds. Theory and Practice of Events Research: Studies in Inter-Nation Actions and Interactions. New York: Gordon \& Breach Science Publishers, 1975.

Banks, Arthur S. "Review of the World Handbook." American Political Science Review 59, no. 1 (1965): 244.

Baratta, Joseph Preston. "The International History of the World Federalist Movement." Peace and Change 14, no. 4 (1989): 372-403.

Baratta, Joseph Preston. "The International Federalist Movement: Toward Global Governance." Peace and Change 24, no. 3 (1999): $340-72$.

Bernard, Jessie. Social Problems at Midcentury: Role, Status, and Stress in a Context of Abundance. New York: Dryden Press, 1957.

Bessner, Daniel. "Weimar Social Science in Cold War America: The Case of the Political-Military Game." GHI Bulletin Supplement 10 (2014): 91-111.

Bessner, Daniel. Democracy in Exile: Hans Speier and the Rise of the Defense Intellectual. Ithaca: Cornell University Press, 2018.

Bessner, Daniel and Nicolas Guilhot. "How Realism Waltzed Off: Liberalism and Decisionmaking in Kenneth Waltz's Neorealism." International Security 40, no. 2 (2015): 87-118.

Bew, John. Realpolitik: A History. New York: Oxford University Press, 2016.

Bueno de Mesquita, Bruce. "Game Theory, Political Economy, and the Evolving Study of War and Peace." American Political Science Review 100, no. 4 (2006): 637-42.

"Correlates of War Project." www.correlatesofwar.org

Craig, Campbell. Glimmer of a New Leviathan: Total War in the Realism of Niebuhr, Morgenthau, and Waltz. New York: Columbia University Press, 2003.

Desch, Michael C. Cult of the Irrelevant: The Waning Influence of Social Science on National Security. Princeton: Princeton University Press, 2019.

Deutsch, Karl. “In Memorium: Quincy Wright." Political Science $\mathcal{E}$ Politics: PS 4, no. 1 (1971): 107-9.

Dryzek, John S. "Revolutions without Enemies: Key Transformations in Political Science." American Political Science Review 100, no. 4 (2006): 487-92.

Elliot, Mai. RAND in Southeast Asia: A History of the Vietnam War. Santa Monica: RAND Corporation, 2010.

Erickson, Paul. The World the Game Theorists Made. Chicago: University of Chicago Press, 2015. 
Fontaine, Philippe. "Stabilizing American Society: Kenneth Boulding and the Integration of the Social Sciences, 1943-1980." Science in Context 23, no. 2 (2010): 221-65.

Freedman, Lawrence. Future of War: A History. New York: Public Affairs Press, 2017.

Frei, Christoph. "Politics among Nations: A Book for America." In Hans J. Morgenthau and the American Experience, edited by Cornelia Navari, 55-74. Cham: Palgrave Macmillan, 2018.

Gilman, Nils. Mandarins of the Future: Modernization Theory in Cold War America. Baltimore: Johns Hopkins University Press, 2003.

Greenberg, Udi. The Weimar Century: German Émigrés and the Ideological Foundations of the Cold War. Princeton: Princeton University Press, 2015.

Griggs, Emily. "A Realist before 'Realism': Quincy Wright and the Study of International Politics between Two World Wars." Journal of Strategic Studies 24, no. 1 (2001): 71-103.

Guilhot, Nicolas, ed. The Invention of International Relations Theory: Realism, the Rockefeller Foundation, and the 1954 Conference on Theory. New York: Columbia University Press, 2011.

Guilhot, Nicolas. After the Enlightenment: Political Realism and International Relations in the Mid-Twentieth Century. New York: Cambridge University Press, 2017.

Gunnell, John G. Descent of Political Theory: The Genealogy of an American Vocation. Chicago: University of Chicago Press, 1993.

Haas, Michael. "Three Approaches to the Study of War." International Journal of Comparative Sociology 11, no. 1 (1970): 34-47.

Harty, Martha, and John Modell. "The First Conflict Resolution Movement, 1956-1971: An Attempt to Institutionalize Applied Interdisciplinary Social Science." Journal of Conflict Resolution 35, no. 4 (1991): 720-58.

Herman, Ellen. Romance of American Psychology: Political Culture in the Age of Experts. Berkeley: University of California Press, 1995.

Horton, Paul B., and Gerald R. Leslie. The Sociology of Social Problems. New York: Appleton-Century-Crofts, 1955.

Kuklick, Bruce. Blind Oracles: Intellectuals and War from Kennan to Kissinger. Princeton: Princeton University Press, 2006.

Kurtz, Lester R. "War and Peace on the Sociological Agenda." In Sociology and Its Publics: The Forms and Fates of Disciplinary Organization, edited by Terence C. Halliday and Morris Janowitz, 61-98. Chicago: University of Chicago Press, 1992.

Latham, Michael E. The Right Kind of Revolution: Modernization, Development, and U.S. Foreign Policy from the Cold War to the Present. Ithaca: Cornell University Press, 2011.

Leonard, Robert J. “War as a 'Simple Economic Problem': The Rise 
of an Economics of Defense." In Economics and National Security: A History of Their Interaction, edited by Crauford D. Goodwin, 261-83. Durham: Duke University Press, 1991.

Leonard, Robert J. Von Neumann, Morgenstern, and the Creation of Game Theory: From Chess to Social Science, 1900-1960. Cambridge: Cambridge University Press, 2010.

McClelland, Charles A. "Acute International Crisis." World Politics 14, no. 1 (1961): 182-204.

Mills, C. Wright. The Causes of World War Three. New York: Simon \& Schuster, 1958.

Morgenthau, Hans. Politics among Nations: The Struggle for Power and Peace. New York: Alfred A. Knopf, 1948.

Morrow, James D., William Clark, Paul F. Diehl, James Lee Ray, Meredith Reid Sarkees, and Thomas C. Walker. "J. David Singer." Political Science \& Politics: PS 43, no. 3 (2010): 590-93.

Oren, Ido. Our Enemies and Us: America's Rivalries and the Making of Political Science. Ithaca: Cornell University Press, 2002.

Parenti, Michael. "Patricians, Professionals, and Political Science." American Political Science Review 100, no. 4 (2006): 499-505.

Pooley, Jefferson. "The Remobilization of the Propaganda and Morale Network, 1947-1953." MediArXiv, July 25, 2018. doi:10.33767/osf.io/g9rp4

Price, David H. Cold War Anthropology: The CIA, the Pentagon, and the Growth of Dual Use Anthropology. Durham: Duke University Press, 2016.

Rohde, Joy. Armed with Expertise: The Militarization of American Social Research During the Cold War. Ithaca: Cornell University Press, 2013.

Rohde, Joy. "Pax Technologica: Computers, International Affairs, and Human Reason in the Cold War." Isis 108, no. 4 (2017): 792-813.

Russett, Bruce M., Hawyard R. Alker, Karl W. Deutsch, and Harold D. Lasswell. World Handbook of Political and Social Indicators. New Haven: Yale University Press, 1964.

Ruzicka, Jan. "A Fetish for Measurement? Karl Deutsch in the Second Debate." International Relations 28, no. 3 (2014): 367-84.

Schneider, Joseph. "Is War a Social Problem?" Journal of Conflict Resolution 3, no. 4 (1959): 353-6o.

Selcer, Perrin. "Patterns of Science: Developing Knowledge for a World Community at UNESCO." PhD diss., University of Pennsylvania, 2011.

Selcer, Perrin. The Postwar Origins of the Global Environment: How the United Nations Built Spaceship Earth. New York: Columbia University Press, 2018.

Simpson, Christopher. Science of Coercion: Communication Research and Psychological Warfare. New York: Oxford University Press, 1996. 
Singer, J. David. "Editor's Introduction." In Quantitative International Politics, edited by J. David Singer, 1-13. New York: Free Press, 1968.

Singer, J. David. "Correlates of War." In Encyclopedia of Peace, Violence, and Conflict, 2nd ed., edited by Lester Kurtz, 449-57. London: Elsevier, 2008.

Singer, J. David, and Melvin Small. The Wages of War, 1816-1965: A Statistical Handbook. New York: Wiley, 1972.

Suzuki, Susumu, Volker Krause, and J. David Singer. "Correlates of War Project: A Bibliographic History of the Scientific Study of War and Peace, 1964-2000." Conflict Management and Peace Science 19, no. 2 (2002): 69-107.

Tanter, Raymond. The Policy Relevance of Models in World Politics. International Data Archive Research Report No. 7. Ann Arbor: Department of Political Science, University of Michigan, October 1971.

Taylor, Charles Lewis, Michael C. Hudson, and Bruce M. Russett. World Handbook of Political and Social Indicators. New Haven: Yale University Press, 1972.

Throntveit, Trygve. "A Strange Fate: Quincy Wright and the TransWar Trajectory of Wilsonian Internationalism." White House Studies 10, no. 4 (2011): 361-77.

Throntveit, Trygve. Power without Victory: Woodrow Wilson and the American Internationalist Experiment. Chicago: University of Chicago Press, 2017.

Tomás Rangil, Teresa. "Rebellions across the (Rice) Fields: Social Scientists and Indochina, 1965-1975." In The Unsocial Social Science? Economics and Neighboring Disciplines since 1945, edited by Roger E. Backhouse and Philippe Fontaine, 105-130. Durham: Duke University Press, 2010.

Tomás Rangil, Teresa. "Finding Patrons for Peace Psychology: The Foundations of the Conflict Resolution Movement at the University of Michigan, 1951-1971." Journal of the History of the Behavioral Sciences 48, no. 2 (2012): 91-114.

Weinberger, Sharon. The Imagineers of War: The Untold History of DARPA, the Pentagon Agency That Changed the World. New York: Alfred A. Knopf, 2017.

Weintraub, E. Roy, ed. Toward a History of Game Theory. Durham: Duke University Press, 1992.

Wright, Quincy. A Study of War. Chicago: University of Chicago Press, 1942.

Wright, Quincy. "Project for a World Intelligence Center." Journal of Conflict Resolution 1, no. 1 (1957): 93-97.

Young, Robert A., James A. Moore, Vivian Moore, et al. Utilization 
of ARPA-Supported Research for International Security Planning, Appendices. Springfield: Consolidated Analysis Centers, Inc., 1972. 